\section{Reserve mobilization in soybean seeds under water restriction after storage}

\author{
Thaísa Fernanda Oliveira ${ }^{1 *}$ (D) Heloisa Oliveira dos Santos ${ }^{1}(\mathbb{D}$, Rafaela \\ Aparecida de Carvalho ${ }^{1}$ iD , Hellismar Wakson da Silva ${ }^{1}$ iD, Raquel Maria de \\ Oliveira Pires ${ }^{1} \mathbb{D}$, Everson Reis Carvalho ${ }^{1}$ iD
}

\begin{abstract}
Germination does not guarantee plant establishment if there is no efficient and enough reserve mobilization from seeds to the initial seedling growth, mainly in adverse situations. Therefore, this study aimed to evaluate the mobilization of reserves in soybean seeds under water restriction. Four soybean seed lots previously stored for one year were used in the study. To simulate water stress, we used polyethylene glycol (PEG) solutions at concentrations of $0.0,-0.1$, and $-0.2 \mathrm{MPa}$. The number of normal, infected and abnormal seedlings were evaluated, along with the number of dead and hard seeds. The radicle, hypocotyl, and cotyledons were separated to determine the dry weight based on the total seed reserve available for mobilization. From this value, the seed reserve reduction, relative dry matter yield, seed reserve reduction rate, and reserve conversion efficiency into dry seedling weight were determined. The increase in water restriction elevates the reserve consumption during the germination process. Vigorous seeds are more efficient in mobilizing and converting grains reserve in dry seedling mass. In less vigorous seeds, mainly those on water restriction, the increase in reserve consumption does not result in conversion into dry seedling mass.
\end{abstract}

Index terms: Glycine max L., osmotic potential, abiotic stress, reserve conversion.

\section{Mobilização de reservas em sementes de soja sob condição de restrição hídrica pós armazenamento}

RESUMO: A germinação não garante o estabelecimento da planta se não houver mobilização eficiente de reservas da semente para o crescimento inicial da plântula, principalmente em situações de estresse. Portanto, objetivou-se avaliar a mobilização de reservas em sementes de soja sob condição de restrição hídrica. Foram utilizados quatro lotes de sementes de soja armazenadas por um ano. Para simular o estresse hídrico foi utilizado soluções de PEG nas concentrações de 0,0,-0,1,-0,2 MPa. Avaliou-se plântulas normais, anormais infectadas e sementes mortas e duras. Para a mobilização de reservas, radícula, hipocótilo e cotilédones foram separados para avaliação da massa seca. A massa seca das sementes foi considerada como o total de reserva disponível para ser mobilizada. A partir disso determinou-se a redução das reservas das sementes, rendimento relativo de massa seca, taxa de redução de reservas e eficiência de conversão de reservas em massa seca de plântulas. $O$ aumento da restrição hídrica aumenta o consumo de reservas das sementes durante a germinação. Sementes mais vigorosas são mais eficientes na mobilização e conversão das reservas em massa seca de plântulas. Em sementes de baixo vigor, principalmente sob restrição hídrica, o aumento no consumo de reservas não resulta em conversão de massa seca de plântulas.

Termos para indexação: Glycine max L., potencial osmótico, estresse abiótico, conversão de reservas.
Journal of Seed Science, v.42, e202042024, 2020

http://dx.doi.org/10.1590/ 2317-1545v42231384

\begin{abstract}
*Corresponding author E-mail: thaisafernanda135@gmail.com
\end{abstract}

Received: $11 / 27 / 2019$. Accepted: 6/10/2020.

\footnotetext{
${ }^{1}$ Departamento de Agricultura/ Sementes, Universidade Federal de Lavras (UFLA), Caixa Postal 3037, 37200-000 - Lavras, MG, Brasil.
} 


\section{INTRODUCTION}

The performance of soybean crops is directly related to the quality of seeds that will be sown in the field (MarcosFilho, 2015; Pereira et al., 2015; Dantas et al., 2017). However, even seeds with superior quality are prone to the deterioration process due to the postharvest techniques and extensive water deficits periods (Bakhshandeh and Gholamhossieni, 2018). This deterioration can directly affect the physiological quality interfering in the emergence of seedlings, resulting in a decrease in the uniformity of plants in the field (Marcos-Filho, 2015; Bakhshandeh and Gholamhossieni, 2018).

The establishment of plants in the field, mainly under stress conditions, will not occur without an efficient mobilization of reserves from seeds to the initial growth of seedlings. The use of soybean seeds more vigorous allows to obtain higher productivity because these seeds have superior content of starch, proteins, sugar and higher capacity in mobilizing these reserves along the germination process (Henning et al., 2010; Pereira et al., 2015; Dantas et al., 2017; França-Neto and Krzyzanowski, 2018).

The mobilization of reserves along the germination process in soybean seeds has a significant role because the embryo starts this process with reserves, keeping its flow of soluble compounds to the parts that are developing (Henning et al., 2010). During the germination process, there are many metabolic activities, with enzymatic reactivation and degradation of substances presented in the endosperm, resulting in energy production and consequently in the formation of structures and embryo development (Taiz and Zeiger, 2013; Pereira et al., 2015; Dantas et al., 2017).

This energy sourced by the degradation of reserves is essential to the development and initial maintenance of seedlings (Taiz and Zeiger, 2013). Because of this, the properties related to the dynamics of seeds reserves are considered as potential characteristics to the evaluation of lots that present higher tolerance to stress conditions (Dantas et al., 2017).

In soybean, from the dry matter content of seedlings, is possible to determine the reduction of reserves in the cotyledons and with this, identify lots that most mobilize dry matter and those which present higher efficiency in converting these reserves in dry matter mass of seedlings (Pereira et al., 2015; Dantas et al., 2017). Considering this, this study aimed to evaluate the mobilization of reserves in soybean seeds under water restriction.

\section{MATERIAL AND METHODS}

The experiment was conducted at the Central Seed Laboratory of the Department of Agriculture of Universidade Federal de Lavras (UFLA). Four lots of soybean seeds from the Monsoy 6410 IPRO cultivar were collected during the $2016 / 2017$ crop season and stored for one year in a cold chamber $\left(10^{\circ} \mathrm{C}\right.$ and $50 \%$ relative humidity). The seeds were standardized by size using a 6-mm sieve.

The four lots used were collected in the same property where were previously reported the production of lots with different physiological quality. The area was divided into squares, and the harvesting process was done in separate access.

The following parameters were determined to mark the seed lots: seedling emergence and emergence speed index (ESI); accelerated aging; electrical conductivity; and viability and vigor, which was analyzed by the tetrazolium test.

The emergence test was conducted in sand and soil substrate in the proportion of 1:2 in polystyrene trays with four replications of 50 seeds per treatment. These trays have been maintained in controlled environment conditions $\left(25^{\circ} \mathrm{C}\right.$ and photoperiod of 12-12 hours). The emergence speed index (GSI) was daily counted, according to Maguire (1962). The results of emergence $(E)$ were expressed in the percentage of healthy seedlings with evaluation at fifteen days after sowing.

To the accelerated aging test, gerbox-type transparent acrylic boxes $(11.0 \times 11.0 \times 3.5 \mathrm{~cm})$ were used, adapted with a hanging aluminum screen, containing $40 \mathrm{~mL}$ of distilled water and a single layer of seeds on the hanging screen. Subsequently, these boxes were kept in a B.O.D. (Biochemical Oxygen Demand) at $41^{\circ} \mathrm{C}$ for 48 hours (Marcos-Filho, 1999). After this period, seeds were submitted to the germination test with four replications of 50 seeds. The counts were done on the seventh day after sowing, and the results were expressed in the percentage of healthy seedlings (Brasil, 2009). 
In the electrical conductivity, four replications of 50 seeds per treatment were immersed in $75 \mathrm{~mL}$ of deionized water. They were kept in a B.O.D germinator type in darkness and constant temperature of $25{ }^{\circ} \mathrm{C}$ according to the methodology described by Vieira and Krzyzanowski (1999). The electrical conductivity of the solution was measured using the conductivimeter equipment's Ms Tecnopon ${ }^{\circledR}$. The results were expressed in $\mu \mathrm{S} . \mathrm{cm}^{-1} \cdot \mathrm{g}^{-1}$ of seed.

For the tetrazolium test, four replications of 50 seeds were used. Seeds were preconditioned between paper towel moistened with distilled water for 16 hours at $25^{\circ} \mathrm{C}$, and then they were immersed in a 2,3,5-triphenyl-2 $\mathrm{H}$ tetrazolium chloride solution at $0.075 \%$ under the temperature of $40{ }^{\circ} \mathrm{C}$ for three hours in the dark. The evaluation was conducted according to the methodology proposed by França-Neto (1999), considering the percentage of vigor and seeds viability.

To simulate water stress polyethylene glycol (PEG 6000) solutions at concentrations of $0.0,-0.1$ and $-0.2 \mathrm{MPa}$ were used (Pereira et al., 2015; Dantas et al., 2017). The four seed lots and the PEG concentration composed a $4 \times 3$ factorial arrangement. Each stress level was obtained by adding PEG 6000 in distilled water at a temperature of $25^{\circ} \mathrm{C}$, according to the recommendations of Villela et al. (1991). These solutions were used to moisten Germitest paper for the germination and reserve mobilization tests.

The germination test was performed on with four replications of 50 seeds using Germitest paper rolls moistened with the PEG 6000 solutions at 2.5 times the weight of the dry paper (Brasil, 2009). The rolls were placed in plastic bags to prevent moisture loss and stored in a germinator at $25^{\circ} \mathrm{C}$. After assembling the test, the evaluation of the healthy seedlings (first count; FC) was performed on the fifth day, and the final count of the healthy seedlings, infected and abnormal seedlings, dead and hard seeds was performed on the seventh day (Brasil, 2009).

For the reserve mobilization test, the Germitest paper was moistened with 2.5 times the weight of the dry paper with the PEG 6000 solutions, and the seeds (four replications of ten seeds) were distributed longitudinally on the upper third of the paper with their micropyles facing toward the paper base (Pereira et al., 2015). The rolls were also placed in plastic bags and stored in a germinator at $25{ }^{\circ} \mathrm{C}$. Seven days after assembling the test, the radicle, hypocotyl, and cotyledons were separated and dried in a forced-air oven at $60 \pm 1{ }^{\circ} \mathrm{C}$ for $72 \mathrm{~h}$. After this period, the plant material was weighed to evaluate the radicle, hypocotyl, cotyledon dry weight, and the values found were subsequently estimated for an equivalent of 50 seedlings (Pereira et al., 2015).

Four replicates of 50 seeds were weighed, placed in an oven at $105{ }^{\circ} \mathrm{C}$ for $24 \mathrm{~h}$, and then weighed again to estimate the total seed reserve available for mobilization (Pereira et al., 2015; Dantas et al., 2017). The other reserve mobilization calculations were performed based on the estimated dry weight values according to the following equations (Pereira et al., 2015):

a. Seed reserve reduction

$$
\text { SRR }=\text { SDM }- \text { CDM }
$$

b. Relative dry matter yield

$$
R D M Y=(R D M+H D M) / 10
$$

c. Reserve reduction rate

$$
S R R R=S R R-R D M Y
$$

d. Conversion efficiency of reserves into dry seedling matter

$$
\mathrm{CESR}=(\mathrm{SDDM} / \mathrm{SRR}) * 100
$$

where

SRR = seed reserve reduction for fifty seeds ( $\mathrm{g}$ )

SDM = estimated dry matter for fifty seeds ( $g$ )

$\mathrm{CDM}=$ estimated dry matter for fifty cotyledon pairs ( $\mathrm{g}$ ) 
$\mathrm{RDMY}=$ relative dry matter yield $(\mathrm{g})$

$\mathrm{RDM}=$ estimated radicle dry matter (g)

$\mathrm{HDM}=$ hypocotyl dry matter $(\mathrm{g})$

SRRR $=$ seed reserve reduction rate $(\%)$

CESR = conversion efficiency of seed reserves into dry seedling matter (\%)

SDDM = estimated dry matter for fifty seedlings (root + shoot)

The data were subjected to analysis of variance using the F-test at $5 \%$ probability. When significant, the variables were compared by Tukey's test. Pearson's correlation analysis at a 5\% probability was also performed.

\section{RESULTS AND DISCUSSION}

The most significant differences among the lots were identified by tests that analyzed vigor, such as ESI, accelerated aging, and dry weight of fifty seedlings (Table 1). According to these tests, the lots were characterized in descending order of quality as follows: lot $2>\operatorname{lot} 3>\operatorname{lot} 1>\operatorname{lot} 4$. There was no significant difference among the lots in terms of the dry weight of fifty seeds $(6.4 \mathrm{~g})$ or for initial moisture $(9.53 \%)$. Even with different lots, the standardization of the seed size for the same cultivar allowed only the difference in quality among the lots to be evaluated regarding reserve mobilization without interference from seed size.

Vigor tests are more sensitive for identifying less advanced stages of seed deterioration and may facilitate decisionmaking regarding the destination of seed lots (Vieira and Krzyzanowski, 1999). Routine tests, such as the germination test, have limitations because they are performed under highly favorable conditions (Brasil, 2009), whereas vigor tests simulate situations that are more compatible with the real conditions in the field.

The tetrazolium test was also performed to classify the seed lots (Table 2). In addition to diagnosing the viability

Table 1. Characterization of soybean seed lots (cultivar Monsoy 6410 IPRO) through seedling emergence, emergence speed index (ESI), accelerated aging, electrical conductivity.

\begin{tabular}{ccccc}
\hline Lot & Seedling Emergence (\%) & ESI & Accelerated Aging (\%) & Electrical Conductivity $\left(\mu \mathrm{S} \cdot \mathrm{cm}^{-1} \cdot \mathrm{g}^{-1}\right)$ \\
\hline 1 & $90 \mathrm{a}$ & $7.89 \mathrm{~b}$ & $42 \mathrm{~b}$ & $100.02 \mathrm{~b}$ \\
2 & $94 \mathrm{a}$ & $8.57 \mathrm{a}$ & $48 \mathrm{a}$ & $94.28 \mathrm{~b}$ \\
3 & $92 \mathrm{a}$ & $8.19 \mathrm{ab}$ & $38 \mathrm{~b}$ & $107.20 \mathrm{~b}$ \\
4 & $75 \mathrm{~b}$ & $6.45 \mathrm{c}$ & $26 \mathrm{c}$ & $150.21 \mathrm{a}$ \\
\hline $\mathrm{CV}(\%)$ & 4.59 & 3.87 & 14.58 & 8.73 \\
\hline
\end{tabular}

Means followed by the same lowercase letter in the column do not differ by Tukey's test at $5 \%$ probability. CV = coefficient of variation.

Table 2. Tetrazolium test (\%) of soybean seed cultivar Monsoy 6410 IPRO.

\begin{tabular}{cccccccccccccc}
\hline Lot & Viability & Vigor & Not Viable & \multicolumn{3}{c}{ Bug Damage } & \multicolumn{1}{c}{ Mechanical Damage } & \multicolumn{1}{c}{ Moisture Damage } \\
\hline \multicolumn{10}{c}{} & \multicolumn{1}{c}{ Classes* } \\
\hline & & & $1-3$ & $4-5$ & $6-8$ & $1-3$ & $4-5$ & $6-8$ & $1-3$ & $4-5$ & $6-8$ \\
\hline 1 & $92.5 \mathrm{a}$ & $68.5 \mathrm{a}$ & $7.5 \mathrm{~b}$ & $2.0 \mathrm{a}$ & $3.5 \mathrm{c}$ & $2.5 \mathrm{a}$ & $22.5 \mathrm{a}$ & $15.5 \mathrm{a}$ & $7.0 \mathrm{~b}$ & $3.5 \mathrm{a}$ & $10.0 \mathrm{a}$ & $2.5 \mathrm{a}$ \\
2 & $92.0 \mathrm{a}$ & $76.5 \mathrm{a}$ & $8.0 \mathrm{~b}$ & $4.5 \mathrm{a}$ & $8.5 \mathrm{~b}$ & $8.0 \mathrm{a}$ & $15.0 \mathrm{a}$ & $7.0 \mathrm{a}$ & $3.5 \mathrm{~b}$ & $0.5 \mathrm{a}$ & $4.0 \mathrm{a}$ & $1.0 \mathrm{a}$ \\
3 & $91.0 \mathrm{ab}$ & $73.5 \mathrm{a}$ & $9.0 \mathrm{ab}$ & $5.0 \mathrm{a}$ & $7.5 \mathrm{~b}$ & $6.0 \mathrm{a}$ & $17.0 \mathrm{a}$ & $8.5 \mathrm{a}$ & $5.5 \mathrm{~b}$ & $3.0 \mathrm{a}$ & $8.0 \mathrm{a}$ & $0.5 \mathrm{a}$ \\
4 & $79.5 \mathrm{~b}$ & $49.5 \mathrm{~b}$ & $20.5 \mathrm{a}$ & $6.0 \mathrm{a}$ & $19.0 \mathrm{a}$ & $11.5 \mathrm{a}$ & $17.0 \mathrm{a}$ & $19.5 \mathrm{a}$ & $18.5 \mathrm{a}$ & $2.0 \mathrm{a}$ & $6.5 \mathrm{a}$ & $3.0 \mathrm{a}$ \\
\hline $\mathrm{CV}(\%)$ & 6.39 & 9.48 & 50.41 & 89.26 & 20.12 & 80.6 & 40.82 & 51.18 & 62.53 & 178.7 & 63.16 & 145.69 \\
\hline
\end{tabular}

Means followed by the same lowercase letter in the column do not differ by Tukey's test at $5 \%$ probability. CV = coefficient of variation.

*Classes established according to França-Neto (1999). 
and vigor of the seed lots, this test describes the potential causes responsible for the decrease in seed quality, such as mechanical damage or deterioration due to moisture and bug damage, which are the most common problems affecting the physiological condition of soybean seeds (França-Neto, 1999).

The seed lots with lower quality had high incidence of mechanical damage (Table 2), which may be related to poor regulation of the harvester and/or processing machinery. Damage to seeds leads to deterioration, which releases free radicals, thus reducing seed viability and vigor as a result of increased lipid peroxidation (Ibrahim, 2016). Post-sowing periods with prolonged water deficits may also contribute to increased deterioration, hindering the physiological potential, which affects seedling emergence and may cause reduction in plant stand in the field.

Seeds subjected to the tests with PEG for water stress simulation had reduced first germination and final germination counts (Table 3). Because the PEG solution has high molecular weight, it does not penetrate seeds and is non-toxic to them. Under controlled conditions, the PEG solute binds to water, reducing the water potential of the solution. This effect induces a reduction in hydraulic conductivity in the membrane system at the contact point, which is similar to water stress in the field (Cochrane et al., 2015).

In the germination test for the control treatment (0.0 MPa) (Table 3) was possible to observe low values than those obtained in the emergence test (Table 1). The non-submission of seeds to pretreatment of imbibition can explain this result. As the water content of seeds was lower than $11 \%$, possibly was an increase in the speed of water absorption (Sediyama-Bhering et al., 2015; Bahry et al., 2017). In the emergence test, the speed of water absorption is lower than in the germination test due to the direct contact with the substrate. Therefore, rapid uptake of water in the germination test can lead to the occurrence of damages in seeds and, consequently, reduction in the percentage of germination (Sediyama-Bhering et al., 2015; Bahry et al., 2017).

The first germination and final germination counts showed reduction greater than $50 \%$ for lots under stress compared to lots under optimal conditions $(0.0 \mathrm{MPa})$. The different water potential values did not differentiate lots

Table 3. Germination of soybean seeds (cultivar Monsoy 6410 IPRO) subjected to water stress.

\begin{tabular}{|c|c|c|c|c|c|c|}
\hline \multirow{3}{*}{ Lot } & \multicolumn{6}{|c|}{ Water Stress (MPa) } \\
\hline & 0.0 & -0.1 & -0.2 & 0.0 & -0.1 & -0.2 \\
\hline & \multicolumn{3}{|c|}{ First Count } & \multicolumn{3}{|c|}{ Germination } \\
\hline 1 & $76 \mathrm{Aa}$ & $24 \mathrm{Ba}$ & $0 \mathrm{Ca}$ & $79 \mathrm{Aa}$ & $57 \mathrm{Bb}$ & $19 \mathrm{Ca}$ \\
\hline 2 & $83 \mathrm{Aa}$ & $18 \mathrm{Ba}$ & $0 \mathrm{Ca}$ & $85 \mathrm{Aa}$ & $69 \mathrm{Ba}$ & $33 \mathrm{Ca}$ \\
\hline 3 & $84 \mathrm{Aa}$ & $17 \mathrm{Bab}$ & $3 \mathrm{Ca}$ & $85 \mathrm{Aa}$ & $49 \mathrm{Bbc}$ & $34 \mathrm{Ca}$ \\
\hline \multirow[t]{2}{*}{4} & $56 \mathrm{Ab}$ & $7 \mathrm{Bb}$ & $0 \mathrm{Ba}$ & $70 \mathrm{Aa}$ & $28 \mathrm{BC}$ & $22 \mathrm{Ca}$ \\
\hline & \multicolumn{3}{|c|}{$\mathrm{CV}(\%)=18.61$} & \multicolumn{3}{|c|}{$\mathrm{CV}(\%)=30.42$} \\
\hline Lot & Defo & ormal & $\begin{array}{c}\text { Infected } \\
\text { Abnormal }\end{array}$ & & & Hard Seeds \\
\hline 1 & & & $12 a b$ & & & $2 a b$ \\
\hline 2 & & & $3 b$ & & & $1 \mathrm{~b}$ \\
\hline 3 & & & $11 \mathrm{ab}$ & & & $\mathrm{Ob}$ \\
\hline 4 & & & $17 \mathrm{a}$ & & & $3 a$ \\
\hline \multicolumn{7}{|c|}{ Stress (MPa) } \\
\hline 0.0 & \multicolumn{2}{|c|}{$12 \mathrm{a}$} & $4 \mathrm{~b}$ & \multicolumn{2}{|c|}{$3 a$} & $2 a$ \\
\hline-0.1 & \multicolumn{2}{|c|}{$35 \mathrm{~b}$} & $12 a b$ & \multicolumn{2}{|c|}{$1 \mathrm{a}$} & $1 \mathrm{a}$ \\
\hline-0.2 & \multicolumn{2}{|c|}{$54 \mathrm{c}$} & $16 \mathrm{a}$ & \multicolumn{2}{|c|}{$1 \mathrm{a}$} & $1 \mathrm{a}$ \\
\hline CV (\%) & \multicolumn{2}{|c|}{33.65} & 79.37 & \multicolumn{2}{|c|}{121.13} & 118.67 \\
\hline
\end{tabular}

Means followed by the same uppercase letter in the column and lowercase letter in the row do not differ by Tukey's test at $5 \%$ probability. CV = coefficient of variation. 
under the -0.2 MPa potential (Table 3).

There was no significant interaction between lots and stress levels for the infected and deformed abnormal seedlings or the hard, dead seeds (Table 3). Lower osmotic potentials resulted in higher numbers of deformed, abnormal seedlings with statistically equal values for all lots regardless of seed quality. The lower quality lots had higher numbers of infected, abnormal seedlings and dead, hard seeds.

There was no significant interaction between lot and water stress levels for seed reserve mobilization (Table 4). For dry matter, the lowest quality lot (lot 4) had lower root weight (RDM). For hypocotyl dry matter, there was no difference among the lots regardless of quality. The highest quality lots showed smaller cotyledon dry matter (CDM) (Table 4). Seed reserve reduction (SRR), or the dry matter remaining in cotyledons, is calculated from the CDM and is indicative of the extent to which the initial reserve present in the cotyledons was reallocated during the seed germination phase.

Regarding the reserve conversion efficiency (CESR) and seed reserve reduction rate (SRRR), there was no difference among the lots (Table 4). However, the relative dry matter yield (RDMY) was higher for the lots with higher quality, which accumulated more dry matter compared to the other lots. These lots were the most efficient in converting the mobilized reserves into dry matter of seedling. Considering that there was no difference among the lots for the initial dry matter reserve to be made available, the efficiency was directly linked to seed quality.

Given the above, it is interesting to consider an increase in the respiratory rate of seeds under stress, where those more vigorous lots showed higher efficiency in the use of the energy released by the respiration. According to this, some researchers observed that vigorous seeds have higher respiratory activity in comparison to those less vigorous seeds, in the same situation and period, showing membrane integrity (Dranski et al., 2013; Venske et al.,2014; Santos et al., 2016). Bewley and Black (2012) described that the mitochondrion integrity in viable embryos increases since the beginning of imbibition process, where is more efficient in the ATP (adenosine triphosphatase) production.

There are differences in the amount of energy available to seeds and their RDMY (Pereira et al., 2015). Some authors have reported that these variables are strongly influenced by seed size and initial weight (Pádua et al., 2010; Pereira et al., 2013). Pádua et al. (2010) and Pereira et al. (2013) correlated a larger seed size with better seedling development, indicating the superiority of large seeds in stand formation.

In practice, however, the dry matter of a seedling originating from a large seed with low reserve mobilization is equal to that of a seedling from a small seed with high reserve mobilization (Pereira et al., 2015). Based on results

Table 4. Reserve mobilization of soybean seeds (cultivar Monsoy 6410 IPRO) subjected to water stress during germination.

\begin{tabular}{ccccccccc}
\hline Lot & $\begin{array}{c}\text { RDM } \\
(\mathrm{g})\end{array}$ & $\begin{array}{c}\text { HDM } \\
(\mathrm{g})\end{array}$ & $\begin{array}{c}\text { CDM } \\
(\mathrm{g})\end{array}$ & $\begin{array}{c}\text { SDDM } \\
(\mathrm{g})\end{array}$ & $\begin{array}{c}\text { SRR } \\
(\mathrm{g})\end{array}$ & $\begin{array}{c}\text { CESR } \\
(\%)\end{array}$ & $\begin{array}{c}\text { RDMY } \\
(\mathrm{g})\end{array}$ & $\begin{array}{c}\text { SRRR } \\
(\%)\end{array}$ \\
\hline 1 & $0.59 \mathrm{a}$ & $0.77 \mathrm{a}$ & $4.08 \mathrm{ab}$ & $1.36 \mathrm{ab}$ & $2.21 \mathrm{~b}$ & $61.68 \mathrm{a}$ & $0.017 \mathrm{bc}$ & $168.08 \mathrm{a}$ \\
2 & $0.58 \mathrm{a}$ & $0.83 \mathrm{a}$ & $3.93 \mathrm{~b}$ & $1.42 \mathrm{a}$ & $2.45 \mathrm{a}$ & $57.29 \mathrm{a}$ & $0.022 \mathrm{a}$ & $131.10 \mathrm{a}$ \\
3 & $0.53 \mathrm{ab}$ & $0.80 \mathrm{a}$ & $4.09 \mathrm{ab}$ & $1.34 \mathrm{ab}$ & $2.33 \mathrm{ab}$ & $57.91 \mathrm{a}$ & $0.020 \mathrm{ab}$ & $156.02 \mathrm{a}$ \\
4 & $0.44 \mathrm{~b}$ & $0.76 \mathrm{a}$ & $4.27 \mathrm{a}$ & $1.20 \mathrm{~b}$ & $2.10 \mathrm{~b}$ & $56.22 \mathrm{a}$ & $0.015 \mathrm{c}$ & $203.17 \mathrm{a}$ \\
\hline Stress (MPa) & & & & & & & & \\
\hline 0.0 & $0.61 \mathrm{a}$ & $1.11 \mathrm{a}$ & $3.62 \mathrm{~b}$ & $1.72 \mathrm{a}$ & $2.75 \mathrm{a}$ & $62.74 \mathrm{a}$ & $0.031 \mathrm{a}$ & $91.31 \mathrm{~b}$ \\
-0.1 & $0.46 \mathrm{~b}$ & $0.64 \mathrm{~b}$ & $4.33 \mathrm{a}$ & $1.10 \mathrm{~b}$ & $2.04 \mathrm{~b}$ & $54.17 \mathrm{ab}$ & $0.016 \mathrm{~b}$ & $133.19 \mathrm{~b}$ \\
-0.2 & $0.55 \mathrm{~b}$ & $0.62 \mathrm{~b}$ & $4.34 \mathrm{a}$ & $1.16 \mathrm{~b}$ & $2.03 \mathrm{~b}$ & $57.92 \mathrm{~b}$ & $0.010 \mathrm{c}$ & $269.28 \mathrm{a}$ \\
\hline $\mathrm{CV}(\%)$ & 20.58 & 17.22 & 5.08 & 12.85 & 9.19 & 13.76 & 31.16 & 54.38 \\
\hline
\end{tabular}

Means followed by the same lowercase letter in the column do not differ by the Tukey test at $5 \%$ probability. RDM = estimated root dry matter for fifty seedlings; HDM = estimated hypocotyl dry matter for fifty seedlings; CDM = estimated dry matter for fifty cotyledon pairs; SDDM = dry matter estimated for fifty seedlings (root + shoot); SRR = seed reserve reduction for fifty seeds; CESR = conversion efficiency of seed reserves into seedling dry matter; RDMY = relative dry matter yield; and SRRR = seed reserve reduction rate. 
Table 5. Pearson linear correlation coefficients for first count $(F C)$, germination (G), estimated root dry matter (RDM), estimated hypocotyl dry matter (HDM), estimated dry matter of fifty seedlings (SDDM), estimated cotyledon dry matter (CDM), seed reserve reduction (SRR), conversion efficiency of seed reserves into seedling dry matter (CESR), relative dry matter yield (RDMY) and seed reserve reduction rate (SRRR).

\begin{tabular}{|c|c|c|c|c|c|c|c|c|c|c|}
\hline & $\mathrm{FC}$ & G & RDM & HDM & SDDM & CDM & SRR & CESR & RDMY & SRRR \\
\hline FC & 1 & & & & & & & & & \\
\hline G & $0.89 *$ & 1 & & & & & & & & \\
\hline RDM & 0.34 & 0.26 & 1 & & & & & & & \\
\hline HDM & $0.82^{*}$ & 0.66 & 0.31 & 1 & & & & & & \\
\hline SDDM & $0.79 *$ & 0.63 & 0.66 & $0.92 *$ & 1 & & & & & \\
\hline CDM & $-0.80^{*}$ & $-0.70 *$ & -0.41 & $-0.83 *$ & $-0.83 *$ & 1 & & & & \\
\hline SRR & $0.79 *$ & $0.70^{*}$ & 0.39 & $0.84^{*}$ & $0.82 *$ & $-0.99 *$ & 1 & & & \\
\hline CESR & 0.32 & 0.17 & 0.67 & 0.49 & 0.66 & -0.16 & 0.13 & 1 & & \\
\hline RDMY & $0.88^{*}$ & $0.70^{*}$ & 0.42 & $0.85^{*}$ & $0.85^{*}$ & $-0.77 *$ & $0.78^{*}$ & 0.45 & 1 & \\
\hline SRRR & -0.52 & -0.57 & -0.32 & -0.45 & -0.48 & 0.27 & -0.27 & -0.49 & $-0.73 *$ & 1 \\
\hline
\end{tabular}

*Significant at $5 \%$ probability by the Pearson linear correlation test.

obtained in the germination of soybean seeds under water stress of $-0.2 \mathrm{MPa}$, Dantas et al. (2017) reported that there is no correlation between the seed size and the characteristics related to reserve dynamics, suggesting that the initial seed size does not influence seed vigor.

Analysis of the correlations among the characteristics (Table 5) indicated that the FC was the variable most correlated with the others. There was a positive correlation of FC with germination (G), HDM, SDDM, SRR and RDMY, but a negative correlation with CDM. Another important result was the negative correlation between the SRRR and RDMY (Table 5). This negative correlation intensifies the idea that the reduction of seeds reserve does not mean direct conversion in dry matter of seedlings.

Additionally, G was negatively correlated with CDM, but positively correlated with SRR and RDMY (Table 5). The dry matter accumulation in the early stages of the plant cycle is essential for the crop because seed germination is followed by mobilization of cotyledon reserves, which contain the necessary energy for growth until seedlings become photoautotrophic (Pritchard et al., 2002).

\section{CONCLUSIONS}

The increase in water restriction elevates reserve consumption during the germination process. Vigorous seeds are more efficient in mobilizing and converting grains reserve in dry mass of seedlings. In less vigorous seeds, mainly those under water restriction, the increase in the reserve consumption does not result in conversion in dry mass of seedlings.

\section{REFERENCES}

BAHRY, C.A.; PERBONI, A.T.; NARDINO, M.; ZIMMER, P.D. Qualidade fisiológica e embebição de sementes de soja com tegumentos contrastantes. Revista Ciência Agronômica, v. 48, n. 1, p. 125-133, 2017. https://doi.org/10.5935/1806-6690.20170014

BAKHSHANDEH, E.; GHOLAMHOSSIENI, M. Quantification of soybean seed germination response to seed deterioration under peginduced water stress using hydrotime concept. Acta Physiologiae Plantarum, v.40, n.7, p.126, 2018. https://link.springer.com/ article/10.1007/s11738-018-2700-1

BEWLEY, J. D.; BLACK, M. Physiology and biochemistry of seeds in relation to germination: volume 2: viability, dormancy, and environmental control. Springer Science \& Business Media, 2012. 
BRASIL. Ministério da Agricultura, Pecuária e Abastecimento. Regras para análise de sementes. Ministério da Agricultura, Pecuária e Abastecimento. Secretaria de Defesa Agropecuária. Brasília: MAPA/ACS, 2009. 395p. https://www.abrates.org.br/files/regras_ analise_de_sementes.pdf

COCHRANE, J.A.; HOYLE, G.L.; YATES, C.J.; WOOD, J.; NICOTRA, A.B. Evidence of population variation in drought tolerance during seed germination in four Banksia (Proteaceae) species from Western Australia. Australian Journal of Botany, v.62, n.6, p.481-489, 2015. https://doi.org/10.1071/BT14132

DANTAS, S.A.G.; SILVA, F.C.S.; SILVA, L.; SILVA, L. Strategy for selection of soybean genotypes tolerant to drought during germination. Genetics and Molecular Research, v.16, n.2, gmr16029654, 2017. http://dx.doi.org/10.4238/gmr16029654

DRANSKI, J.A.L.; PINTO JR, A.S.; HERZOG, N.F.M.; MALAVASI, U.C.; MALAVASI, M.D.M.; GUIMARÃES, V.F. Vigor of canola seeds through quantification of $\mathrm{CO}_{2}$ emission. Ciência e Agrotecnologia, v.37, n.3, p.229-236, 2013. https://doi.org/10.1590/S141370542013000300005

FRANÇA-NETO, J.B. Testes de tetrazólio para determinação do vigor de sementes. In: KRZYZANOWSKI, F.C.; VIEIRA, R.D.; FRANÇANETO, J.B. (ed.). Vigor de sementes: conceitos e testes. Londrina: ABRATES, 1999. p.1-28.

FRANÇA-NETO, J.B.; KRZYZANOWSKI, F.C. Metodologia do teste de tetrazólio em sementes de soja. Londrina: Embrapa Soja, 2018. 108p. (Embrapa Soja. Documentos, 406).

HENNING, F.A.; MERTZ, L.M.; JACOB-JUNIOR, E.A.; MACHADO, R.D.; FISS, G.; ZIMMER, P.D. Composição química e mobilização de reservas em sementes de soja de alto e baixo vigor. Bragantia, v.69, n.3, p.727-733, 2010. http://dx.doi.org/10.1590/S000687052010000300026

IBRAHIM, E.A. Seed priming to alleviate salinity stress in germinating seeds. Journal of Plant Physiology, v.192, p.38-46, 2016. https://doi.org/10.1016/j.jplph.2015.12.011

MAGUIRE, J.D. Speed of germination -aid in selection and evaluation for seedling emergence and vigor. Crop Science, v.2, n.2, p.176-177, 1962. https://dl.sciencesocieties.org/publications/cs/abstracts/2/2/CS0020020176

MARCOS-FILHO, J. Fisiologia de sementes de plantas cultivadas. Londrina: ABRATES, 2015. 660p.

MARCOS-FILHO, J. Testes de envelhecimento acelerado. In: KRZYZANOWSKI, F.C.; VIEIRA, R.D.; FRANÇA-NETO, J.B. (Ed.) Vigor de sementes: conceitos e testes. Londrina: ABRATES, 1999. p.3.1-3.21.

PÁDUA, G.P.; ZITO, R.K.; ARANTES, N.E.; FRANÇA-NETO, J.B. Influência do tamanho da semente na qualidade fisiológica e na produtividade da cultura da soja. Journal of Seed Science, v.32, n.3, p.9-16, 2010. http://www.scielo.br/pdf/rbs/v32n3/v32n3a01.pdf

PEREIRA, W.A.; PEREIRA, S.M.A.; DIAS, D.C.F.S. Dynamics of reserves of soybean seeds during the development of seedlings of different commercial cultivars. Journal of Seed Science, v.37, n.1, p.63-69, 2015. http://dx.doi.org/10.1590/2317-1545v37n1142202

PEREIRA, W.A.; PEREIRA, S.M.A.; DIAS, D.C.F.S. Influence of seed size and water restriction on germination of soybean seeds and on early development of seedlings. Journal of Seed Science, v.35, n.3, p.316-322, 2013. http://www.scielo.br/pdf/jss/v35n3/07.pdf

PRITCHARD, S.L.; CHARLTON, W.L.; BAKER, A.; GRAHAM, I.A. Germination and storage reserve mobilization are regulated independently in Arabidopsis. The Plant Journal, v.31, n.5, p.639-647, 2002. http://dx.doi.org/10.1046/j.1365-313X.2002.01376.x

SANTOS, H.O.; VON PINHO, I.V.; VON PINHO, É.V.R.; PIRES, R.M.O.; SILVA, V.F.; CARVALHO, M.L.M.; OLIVEIRA, R.M.E. Physiological quality of hybrid maize seeds through respiratory and enzymatic activities. African Journal of Agricultural Research, v.11, n.20, p.1879-1886, 2016. http://dx.doi.org/10.5897/AJAR2015.10457

SEDIYAMA-BHERING, C.A.Z.; SOARES, C.Q.G.; AMORA, D.X.; NOBRE, D.A.C.; SEDIYAMA, C.S.; DIAS, D.C.F.S.; REIS, M. S. Imbibition profile in polyethylene glycol 6000 osmotic solution and physiological potential of soybean seeds. Revista Brasileira de Ciências Agrárias, v. 10, n. 3, p. 376-381, 2015. http://dx.doi.org/10.5039/agraria.v10i3a4529

TAIZ, L.; ZEIGER, E. Fisiologia Vegetal, Porto Alegre: Artmed, 2013. 918p.

VENSKE, E.; JÚNIOR, J.D.S.A.; SOUSA, A.D.M.; MARTINS, L.F.; MORAES, D.M. Atividade respiratória como teste de vigor em sementes de algodão. Revista Brasileira de Ciências Agrárias, v.9, n.2, p.174-179, 2014. http://dx.doi.org/10.5039/agraria.v9i2a3518

VIEIRA, R.D.; KRZYZANOWSKI, F.C. Teste de condutividade elétrica. In: KRZYZANOWSKI, F.C.; VIEIRA, R.D.; FRANÇA-NETO, J.B. (Ed.) Vigor de sementes: conceitos e testes. Londrina: ABRATES, 1999. p.4.1-4.26.

VILLELA, F.A.; DONI-FILHO, L.; SEQUEIRA, E.L. Tabela de potencial osmótico em função da concentração de polietilleno glicol 6.000 e da temperatura. Pesquisa Agropecuária Brasileira, v.26, n.11/12, p.1957-1968, 1991. 